Historic, Archive Document

Do not assume content reflects current scientific knowledge, policies, or practices. 



\section{Fall Catalog of Bulbs}

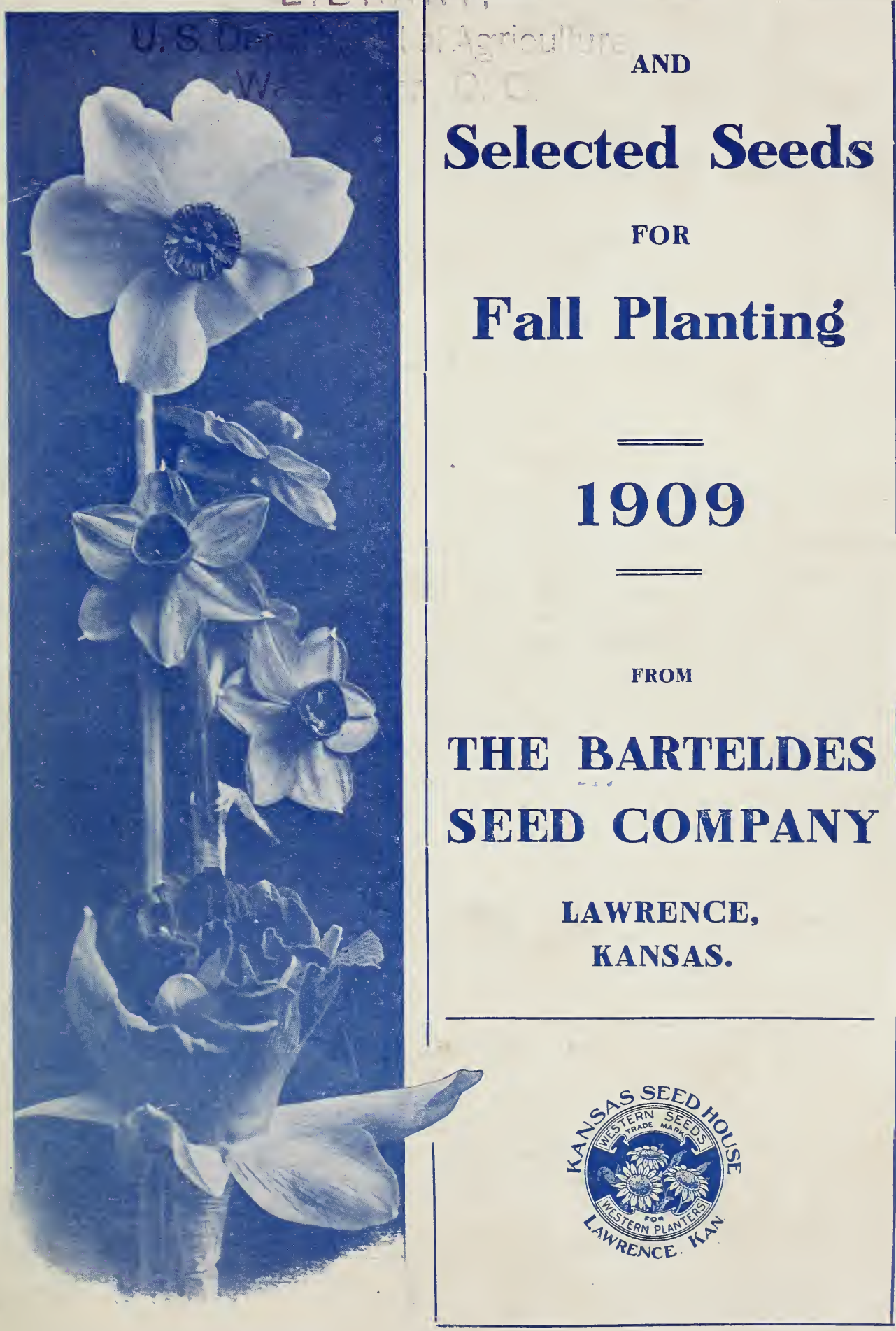




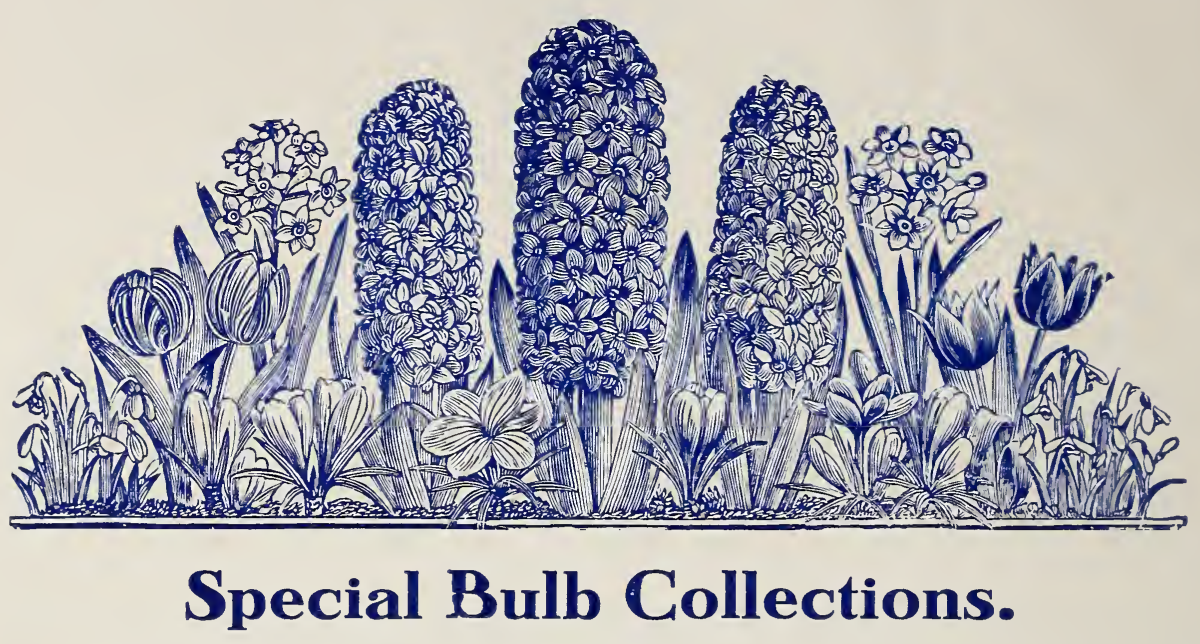

Oftentimes people leave to us the selection for a certain amount of money, thus we have decided to compile several collections of easy growing varieties. OUR SELEction:

\section{COLLECTION No. 1 \\ FOR HOUSE CULTURE. EARLY BLOOMING.}

This assortment will fill a window box for an ordinary window. The box should be 3 feet long, 6 inches wide by 6 inches deep. Plant the bulbs in rows, each variety in a row.

12 Hyacinths, single and double assorted.................................... $\quad 85 \mathrm{c}$

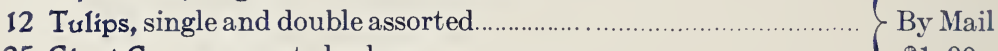

25 Giant Crocus, assorted colors ……............................................. $\$ \$ 1.00$

COLLECTION No. 2

FOR HOUSE CULTURE. EARLY BLOOMING.

12 Narcissus, Paper White Grandiflora

21 Roman Hyacinths, White, early

25 Freesias, all white.

\section{COLLECTION No. 3}

FOR HOUSE CULTURE. MID-WINTER BLOOMING.

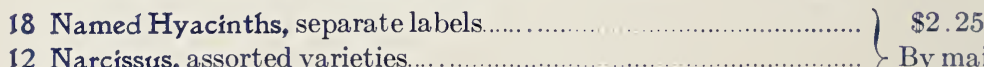

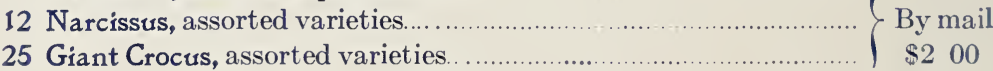

\section{COLLECTION No. 4}

FOR HOUSE CULTURE. LATE-WINTER BLOOMING.

12 Named Hyacinths, separate labels.

6 Narcissu, Daffodils, assorted

25 Tulips, named varieties.

12 Giant Crocus, separate varieties

3 Easter Lilies

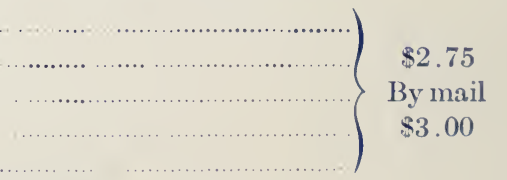

\section{COLLECTION No. 5 \\ FOR OUT-DOOR PLANTING.}

This contains the best combination of colors procurable. They will bloom about the same time in early spring. This quantity will plant a bed six feet in diameter with bulbs to average four inches apart in the rows, with the rows about six inches apart.

18 Named Hyacinths, separate labels

100 Named Tulips, separate labels.

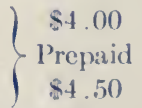

100 Giant Crocus, separate colors

$\$ 4.50$

We would suggest the Crocus for the border, next the Tulips, with the Hyacinths for the center. 


\title{
KANSAS SEED HOUSE
}

\section{THE BARTELDES SEED CO.}

\author{
LAWRENCE, KANSAS.
}

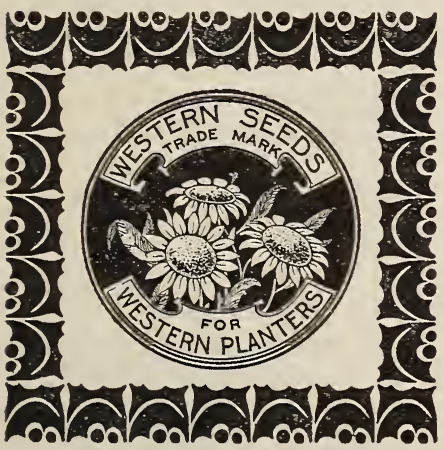

AUGUST 15, 1909.

\section{Friends and Customers:}

NOW is the time to make preparations by ordering bulbs, the flowers of which will help to beautify your home next winter, and next month you should plant some of the early varieties if you want flowers in the house at Christmas time. If you take our advice you will get your order ready soon, and will not wait until the rough autumn winds remind you of the approach of the cold season. Frequently toward the middle of November we have to report "Sold Out" on most of the varieties.

The Culture directions, which you will find throughout this catalog, will help to make your work successful. Plan your flower beds around your home, get pots and glasses ready, and let us send you bulbs, which will produce flowers and add to the beauty and attraction of your home.

IF YOU ARE A BEGINNER, and are in doubt which varieties you should plant, LET US HELP you. We recommend as a most convenient thing the collections offered on the opposite cover page. They contain first class bulbs (as ALL of our bulbs are) and will give general satisfaction. Let us hear from you soon! We shall try to please you.

Our large annual catalog will be issued about January 1st. If you have not been receiving it regularly, drop us a line to that effect and we will see that your name is placed on our mailing list.

Respectfully yours,

\section{The Barteldes Seed Co.}




\section{How to Order, and Terms.}

USE THE ENCLOSED ORDER SHEET, signing your name and address very plainly. Often times we receive orders which we are unable to fill, owing to the fact that customers forgot to sign their names.

KEEP A COPY OF YOUR ORDER. Quite frequently it happens that customers complain about not receiving this or that, when in reality they never ordered the items in question. A returning of the original order sheet usually convinces the customer of his error, but all of this can be avoided if a correct copy is kept by the sender of the order.

SEND CASH ALONG WITH ORDER. You may remit at our risk either by post office money order, bank draft, or check, express order or cash by registered letters. We guarantee the safe arrival of all shipments of bulbs or seeds, whether sent by mail, express or freight.

TIME OF SHIPMENT. Most of the bulbs are ready to be shipped by the middle of September. However, we have printed under the various headings and varieties the approximate time at which we expect to be able to make shipments.

ABOUT MAILING. All bulbs and seeds will be sent postage paid or prepaid by Express. except where otherwise stated.

All orders amounting to $25 \mathrm{c}$ or over will be acknowledged by return mail.

FINALLY, we wish to urge you to send us your orders as early in the season as possible. We are quite ready to book orders now, and shall execute them as soon as our import shipments arrive. First come, first served and we cannot replace most varieties after our stock is exhaust-. ed.

\section{The Barteldes Seed Co.}

\section{INDEX.}

\begin{tabular}{|c|c|c|}
\hline Page. & Page. & Page \\
\hline back of cover & Freesia... & Lawn Grass..................... \\
\hline Amaryllis.. & Gras & Rape, Dwarf Essex... \\
\hline Anemone.. & Hyacinths. & Rye.. \\
\hline Barley.... & Iris...... & Sacred Li \\
\hline Bermuda 1 & Jong & Scilla. \\
\hline Calls & Jos & Sno \\
\hline Chir & Lili & Sw \\
\hline Clor & 6 & \\
\hline 7 & 12 & $\mathrm{Ve}$ \\
\hline 9 & $\ldots 11$ & Vic \\
\hline 6 & $\ldots 12$ & Wheat... \\
\hline Flower Seeds. & Lily of the Valley ......... & Winter Barley...... \\
\hline
\end{tabular}




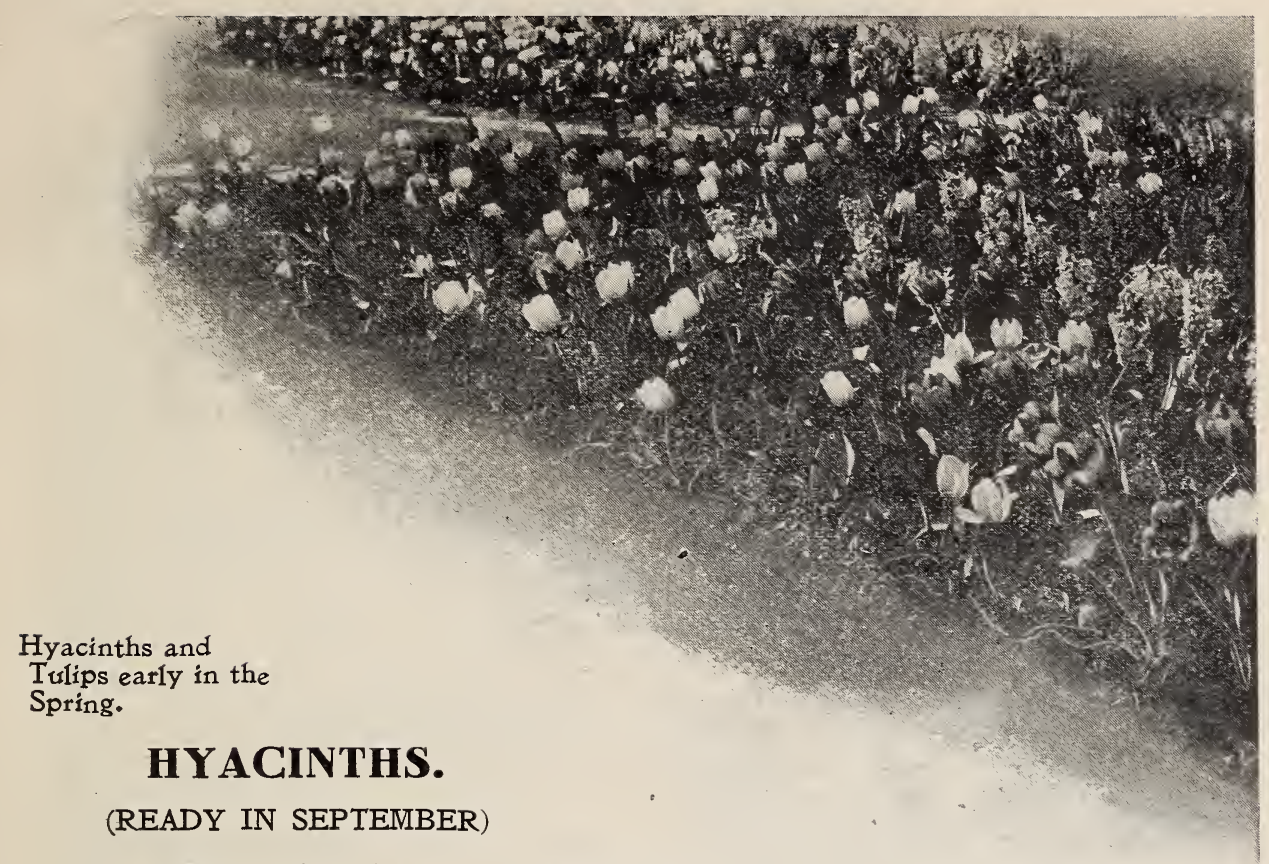

CULTURE. If planted outside for early spring blooming, the bulbs should be planted from 3 to 4 inches deep, according to the soil. In soils light and sandy the deeper planting is the better, but in heavy loam, two or three inches is deep enough. Plant as early in the fall as possible, as the bulbs are in active growth under the ground during the fall and winter, and when the frost enters the ground it checks the growth. A covering of straw or coarse manure would keep the frost out, then the plants would be strong$\mathrm{er}$, the flowers larger and earlier. In planting all kinds of bulbs in the fall a good supply of wellrotted manure should be worked into the ground before the bulbs are put in their places

For Pot Culture no plant can succeed better than the Hyacinth. Prepare the pots carefully as to drainage and fill them with the best soil you can get. Plant the bulb about one inch below the surface, water thoroughly and put away in a dark cellar or bury them, pot and all, in the garden where they can be reached at any time and cover the pots eight or ten inches deep. Let them stand there for six or seven weeks and then bring them into the house, a few at a time. A four inch pot is the best size for a single bulb and a six or eight inch bulb pan will hold three to five bulbs. During their growth in the house they should be kept near the light (avoiding direct sun), well watered, and in a temperature of 50 to 70 degrees.

To Grow Hyacinths in Glasses fill them with water to reach the base of the bulbs and fill whenever evaporated. Place a small piece of charcoal in the water to keep it sweet, and keep in a cellar till well rooted, then bring to the light, but never to a very warm place.

\section{SELECT 3 NAMEDHYACINTHS.}

All the Hyacinths offered by us are first-size only, of perfect blooming qualities and are not in any way to be compared with cheap case-bulbs, brought over to this country on speculation.

If ordering by the dozen, shipment to be made by mail, add 15 cents for postage for every dozen of large named varieties and 10 cents extra for every dozen of mixed and not named sorts. Three bulbs of one kind at the dozen rate. 


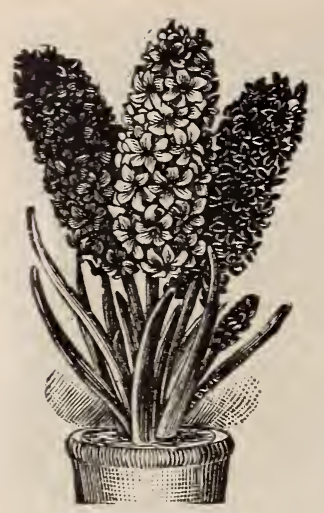

Double Hyacinths.

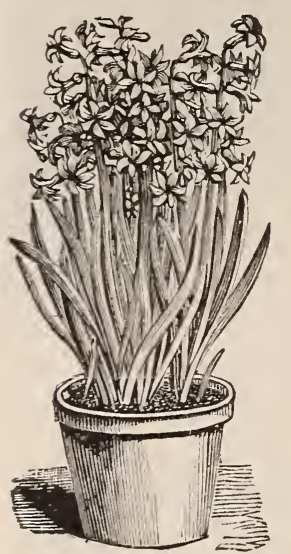

Roman Hyacinths.

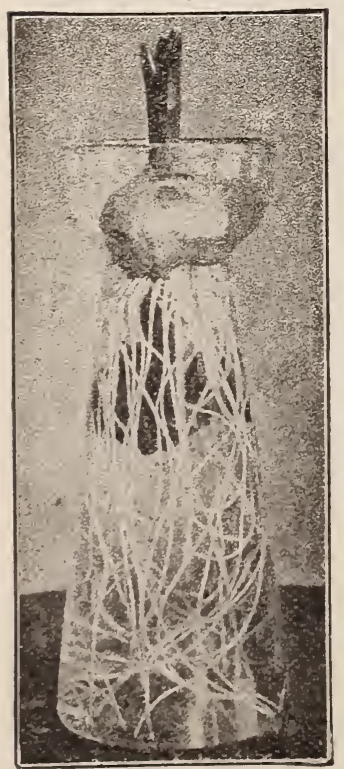

Hyacinth Glass.

SINGLE VARIETIES ASSORTED"as to Colors BEST FOR FORCING"AS WELL AS OUTDOOR"CULTURE

NAMED RED AND ROSE HYACINTHS Each Doz.

Amy, bright carmine. $\$ 0.12 \$ 1.25$ Lord Wellington,

Garibaldi, glossy pale pink ...... \$0.12

Each Doz.

crimson

.15

1.50

Queen of Hyacinths

Giganthea, blush rose $\quad .12 \quad 1.25$ bright crimson $\quad .15$

Gertrude, rosy pink.

1.25

\section{NAMED WHITE AND BLUSH HYACINTHS}

Alba Superbissima, pure white..........................................\$0.15

Crown Princess, pure white.................................................... .15

Grandeur a Merveille, rosy white....................................... .12

Queen Victoria, pure white.................................................. . .15

$\$ 1.50$

1.50

1.25

1.50

NAMED LIGHT AND DARK BLUE HYACINTHS

Grand Maitre, deep porcelain blue.................................. $\$ 0.12$

King of the Blues, dark purplish blue................................. .12

La Peyrouse, clear porcelain blue ..................................... . $\quad .12$

Mimosa, purplish black .................................................... $\quad .12$

Queen of the Blues, sky blue................................................... .15

NAMED YELLOW AND ORANGE HYACINTHS

Duc de Malakoff, salmon, striped orange......................... $\$ 0.12$

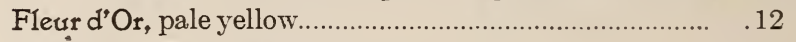

King of the Yellows, deep yellow ................................... .15

La Plurie d'Or, pale yellow.

$12 \quad 1.25$

NAMED PURPLE, LILAC AND MAUVE HYACINTHS

Amie du Coeur, early lilac...............................................\$0.12 $\$ 1.25$

Distinction, maroon .............................................................. $\quad .15 \quad 1.50$

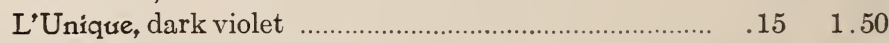

W. Mansfield, purplish mauve.......................................... $\quad .15 \quad 1.50$

\section{HYA CINTHS, SELECTED TO COLORS.}

VER Y LARGE SIZE, SINGLE BULBS 10 CENTS EACH.

SINGLE VARIETIES FOR BEDDING PURPOSES

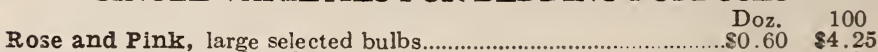

White, large selected bulbs.............................................................. $.60 \quad \begin{aligned} & \$ .25 \\ & 4\end{aligned}$

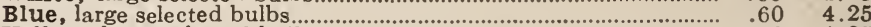

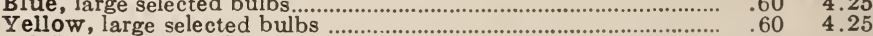

All Colors mixed, large selected buibs................................................ $.60 \quad 4.00$

DOUBLE VARIETIES FOR INDOOR CULTURE.

SINGLE BULBS 10 CENTS EACH. SELECTED BULBS.

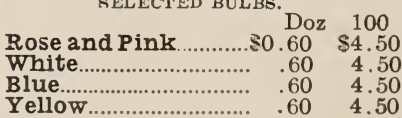

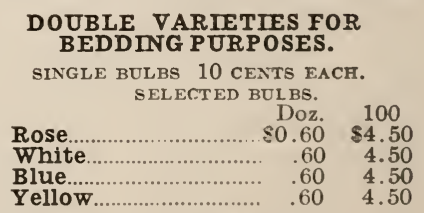

TRUE FRENCH ROMAN HYACINTHS. Readyabout Sept. I

These are mostly used for forcing. They produce pure white, delightfully fragrant flowers, each bulb throwing from three to four spikes. Usually three or four bulbs are planted in one pot.

Pure White, selected bulbs, 5 cents each, 50 c per doz.; $\$ 3.75$ per hundred.

MINIATURE OR "DUTCH ROMAN" HYACINTHS.

Very suitable for ${ }_{i}^{-}$growing in pots and pans. We offer them in separate colors as follows:

Single White, Dark Blue, Pink, Dark Red, 40c per doz.; $\$ 2.75$ per 100.

All colors mixed, 40c per doz.; $\$ 2.50$ per 100. HYACINTH GLASSES.

These are very attractive for window and table display, each glass bolding a hyacinth bulb, showing root growth in the water, These glasses are most excellent bouquet vases. Each 2 for Doz.

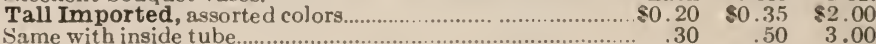




\section{TULIPS.}

\section{(READY FOR DELIVERY IN SEPTEMBER.)}

Tulips, because of the brilliancy of their color, their beautiful graceful shape, and their easy culture, are among the most valued of spring flowering bulbs. They are unrivaled for bedding use, producing gorgeous effects by their contrasting colors.

CULTURE.-The cultural directions for Hyacinths, given on page 3, are also applicable to Tulips, except that the bulbs being smaller should not be planted more than 4 inches deep and 6 inches apart. Use old well-rotted manure to enrich the ground, and, if the same is heavy, some sand should be mixed in. Plant in October or November, before the ground freezes. For indoor culture treat the same as Hyacinths, but planting from 3 to 5 bulbs in a 5 -inch pot.

\section{NAMED SINGLEJVARIETIES}

If ordered by [mail add 5 cents per dozen or 30 cents per hundred for Postage. at the 100 rate.

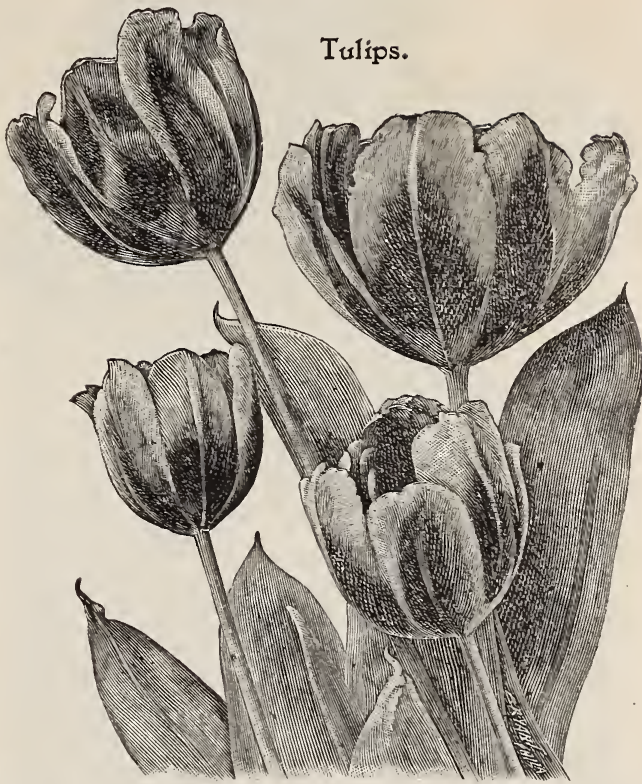

Artus. Bright scarlet, of dwarf habit, very showy, each $5 \mathrm{c}$.

Californian Gold. A beautiful yellow variety, each $5 \mathrm{c}$...........

oz. $\quad 10$

Crimson King. Large bright crimson flower, each $5 \mathrm{c}$.

$\$ 0.35 \quad \$ 2.25$

Jacht van Delft. Pure white, fine cup shapped, 3 for $10 \mathrm{c}$

.35

$.40 \quad 2.50$

Keizerskroon. Red with golden yellow border, each $5 \mathrm{c} . .$.

$.25 \quad 1.50$

Koh-i-noor. Very dark cimson, margined golden yellow, grand variety, €ach $1 \mathrm{C} c \quad .80 \quad 5.00$

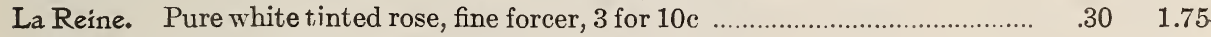

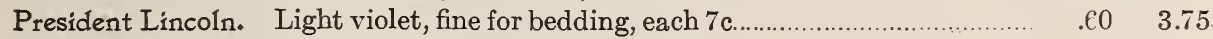

\section{NAMED DOUBLE VARIETIES.}

If ordered by mail, add 5 cents per dozen or 30 cents per hundred for pestace. Six of one kind at the dozen rate; 25 of one kind at the 100 rate.

Duke of York. Carmine rose, bordered with white, each $5 \mathrm{c}$.

Doz. $\quad 100$

Grand Alexander. Velvety brown edged with yellow, each $5 \mathrm{c}$

$\$ 0.35 \$ 2.00$

La Candeur. Pure white, very large, fine for bedding, each 5c.

$.40 \quad 2.50$

Michael Angelo. Red and yellow, magnificent variety, each 7c

$.40 \quad 2.50$

Velvet Gem. Dark carmine, extra large flowers, each $5 \mathrm{c}$.

$.60 \quad 3.50$

$.40 \quad 2.50$

\section{MIXED SORTS.}

The Duc van Tholl Tulips bloom out doors before any of the earliest named rarieties They are of dwarf habit and are equally well adapted for forcing as well as bedding purposes.

Duc van Tholl, finest single mixed each $5 \mathrm{c}$ Doz. 100

Duc van Tholl, good single mixed, 2 for $5 \mathrm{c}$. $\$ 0.25 \quad \$ 1.75$

Duc van Tholl, best double mixed, each $5 \mathrm{c}$ 


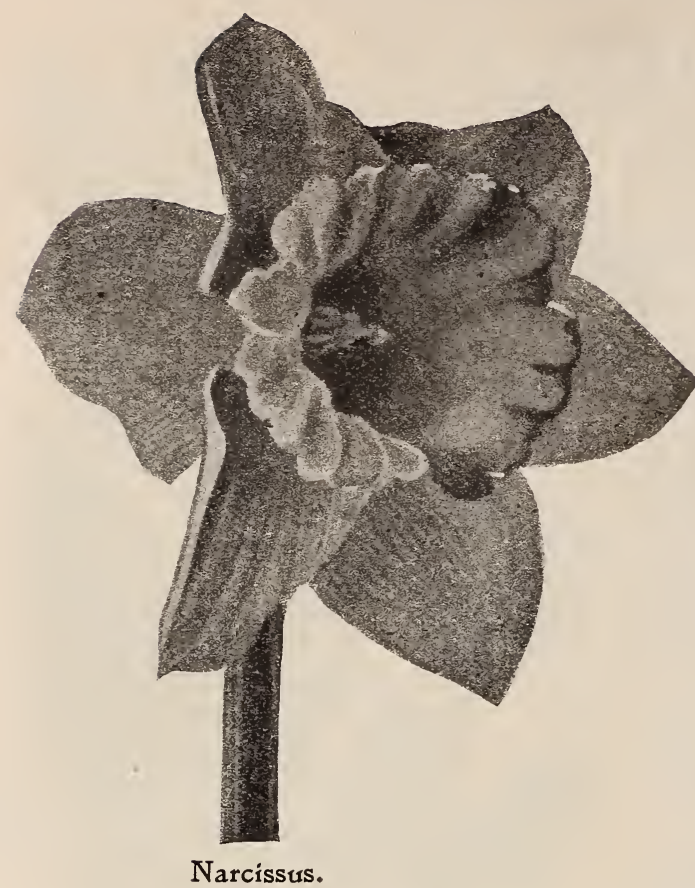

\section{NARCISSUS.}

\section{READY FOR DELIVERY IN SEPTEMBER.}

For beanty and grace combined with fragrance and hardiness, the Narcissus carry easily first prize among the bulbous spring flowering plants. They are very easily cultivated, growing in any good garden soil, are perfectly hardy and just as well adapted for forcing as for open ground. Treatment is much the same as for Hyacinths, only of course they do not have to be planted so deep_and so far apart.

\section{SINGLE NARCISSUS or DAFFODILS.}

If ordered to be sent by mail, add 10 cents per dozen for postage.

Doz. 100

Bicolor Horsfieldi. "Queen of Daffodils." Large golden yellow trumpet with pure white petals or wings. A grand variety, excellent, for forcing, and producing a magnificent flower. Each 5 c.

.$\$ 0.50 \quad \$ 3.00$

Trumpet Maximus. Extra fine large yellow flowers. Each 5c.

$60 \quad 3.50$

Poeticus ornatus. (Pheasant's Eye.) Grand variety of pure white"color with orange center. Illustated on the front cover by the uppermost, flower.

Each 5c..

Princeps Maximus. Of sulphur yellow petals or wings with deep vellow trumpet. A splendid sort, producing handsome flowers. Each $5 \mathrm{c}$

Paper White Grandiflora. This magnificent variety is largely used for forcing. It produces beautiful clusters of pretty pure white flowers which are exquisitely fragrant. Can.easily be had in bloom by Christmas. Each 5c

\section{DOUB LEMNARCISSUS.}

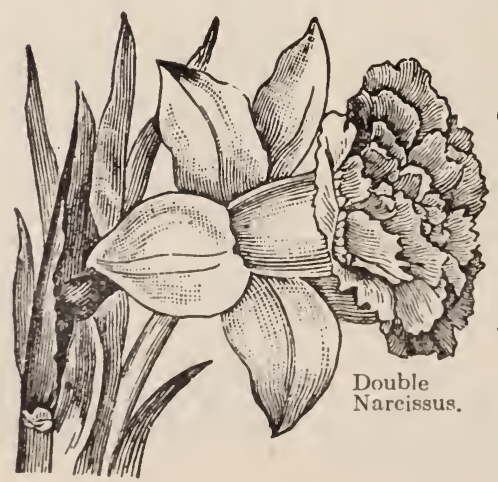

If ordered to be sent by mail, add $10 \mathrm{c}$ per dozen for postage.

Grand Soleil d'0r. This variety"really'beDoz. 100 longs to the class of the "Polyanthus"

Narcissus. As the center picture in our illustration on the front cover shows. it is a cluster-flowering Daffodil. The flowers are yellow with orange cup and exceedingly fragrant. Each $5 \mathrm{c} \ldots$...

Van Sion. The most popular Dutch Daffodil in existence. It is illustrated at the top of this page. Large, pure golden yellow flowers with single nose. Fine sclected bulbs. Each 5c 


\section{JONQUILS.}

A species of Narcissus easily grown in house or garden, much admired for its bright yellow and deliciously fragrant flowers.

Double Yellow. Each 4c, doz. 30c, postpaid.

\section{CHINESE NARCISSUS OR ORIENTAL SACRED LILY.} (READY IN SEPTEMBER.)

If first size bulbs are ordered by mail, add 25 cents per dozen for postage.

Call by some Joss Flower. This variety is grown by Chinamen for decorating their windows and temples for their New Year Festivals in February. The wonderful rapidity of growth and number of fragrant blossoms, from a single bulb, has made this flower a favorite.

Being partially aquatic it must have plenty of water. If grown in earth it must be sandy and light; but they are generally grown in bowls or dishes of water. Take a bowl about 3 inches deep, set your bulbs in the center and fill the bowl with gravel or shells to keep the plants from falling over, put water in the dish and set in a dark closet for a few days / until the roots start freely; then bring them to the light or keep in the living room.

First size bulbs 10c each; per dozen, not prepaid, $\$ 1.00$; a basket of 30 bulbs for $\$ 2.00$.

A limited supply of extra large bulbs, $15 \mathrm{c}$ each, 3 for $40 \mathrm{c}$, postpaid.

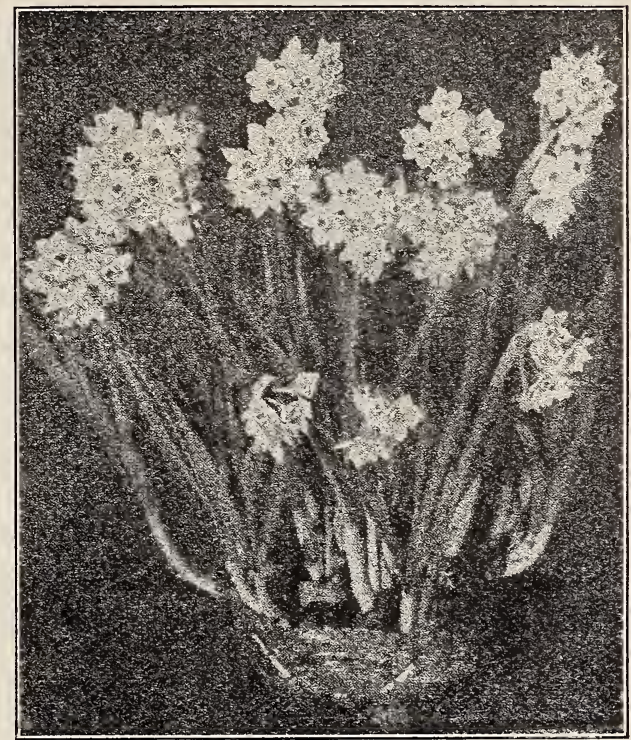

Chinese Sacred Lily.

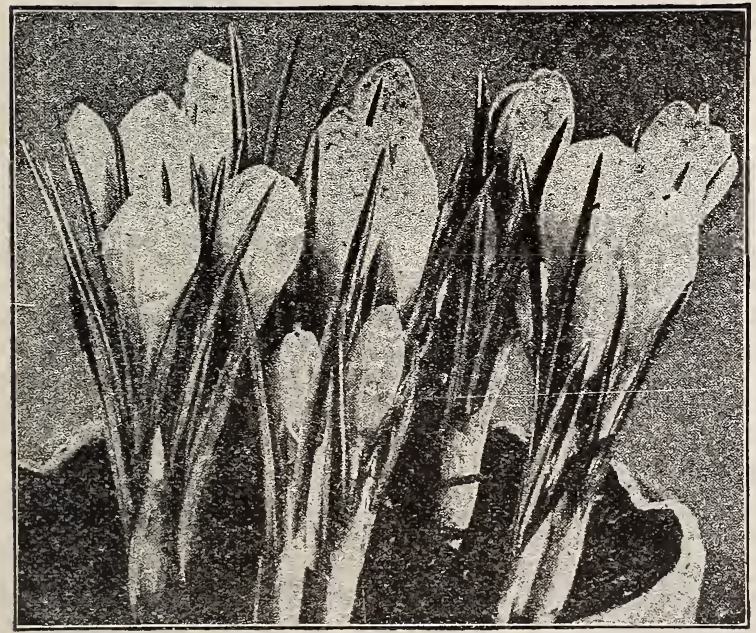

Crocus.
CROCUS. (READY IN SEPTEMBER)

The bulbs should be planted three inches deep; the object of deep planting being that, as the new bulb is formed annually on thetop of the old one, they soon get too near the surface. They should be planted in the early fall or they are liable to start growing, which spoils the flowers for the coming season. Being perfectly hardy they are among the first ones to bloom in the spring, often before the snow has disappeared. The best effect is in masses in beds, arranging colors as desired. They can also be set one here and there on the lawn. Simply lift the turf with a trowel and insert the bulbs about three inches deep. The tops will die down to the surface in time for lawn cutting. They bloom several years.

For indoors, treat same as Hyancinths.

Giant White, can be used for pot culture as well as for bedding Giant Blue, can be used for pot culture as well as for bedding...... Giant Yellow, can be used for pot culture as well as for bedding Giant Striped, can be used for pot culture as well as for bedding Common Size, mixed, for bedding only
Doz. $100 \quad 1000$

$\$ 0.10 \quad \$ 0.60 \quad \$ 4.50$

$\begin{array}{lll}10 & .60 & 4.50\end{array}$

$\begin{array}{lll}10 & .60 & 4.50\end{array}$

$\begin{array}{lll}10 & .60 & 4.50\end{array}$

$\begin{array}{lll}10 & .40 & 3.00\end{array}$ 


\title{
General List of Various Other Varieties of Bulbs.
}

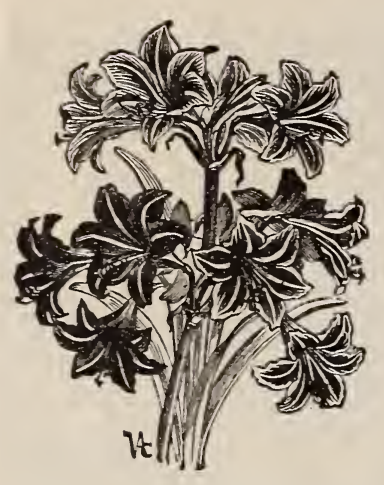

Amaryllis.

\section{AMARYLLIS.}

\author{
(READY IN OCTOBER)
}

CULTURE. The chief value of the Amaryllis is to produce flowers in the winter season, which they readily do if they are kept dry and dormant the latter part of summer and autumn; and with a number of bulbs, a succession of flowers may be had the entire year. Use small pots and do not put in larger until there is danger of the bulbs bursting the pot, and then be careful not to disturb the ball or earth. The bulbs should not be covered more than half, and, after they have bloom, when the leaf growth commences, they should have a good supply of liquid manure once a week.

The Amaryllis Formosissima (Jacobean Lily) should be grown out of doors and treated precisely the same as the gladiolus. Cover the bulbs about 3 inches deep and, after the frost, take up, cut the tops to within 3 inches of the bulbs and keep in a dark place out of the frost. A peculiar feature of the Amaryllis is, that the flower comes before the leaves when indoors, and after the leaves when in open ground.

Amaryllis Formosissima, each 15c; 4 for 50c, postpaid.

\section{ANEMONES-(Wind Flower.)}

\section{(READY IN NOVEMBER)}

One of the most beautiful and showyiflowers, with compact growth. Needs to be seen to be appreciated. For outdoors, plant bulbs 3 to 4 inches deep and protect through first winter, with leaves or manure. For indoors, plant 3 or 4 bulbs in a 5 -inch pot, keep in a cool place until growth appears, then remove to sitting room window. Avoid heat and dry air. Price includes postage. Each Dozen Single, mixed. .$\$ 0.05 \$ 0.20$ Double, mixed .05 .25

\section{CALLA LILIES. (READY IN SEPTEMBER)}

The Calla is one of the best winter flowering plants

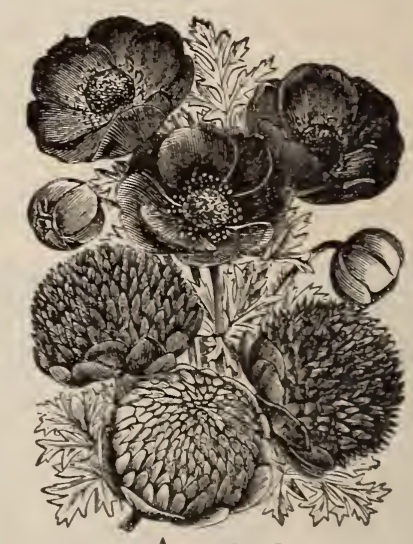

Anzmones.

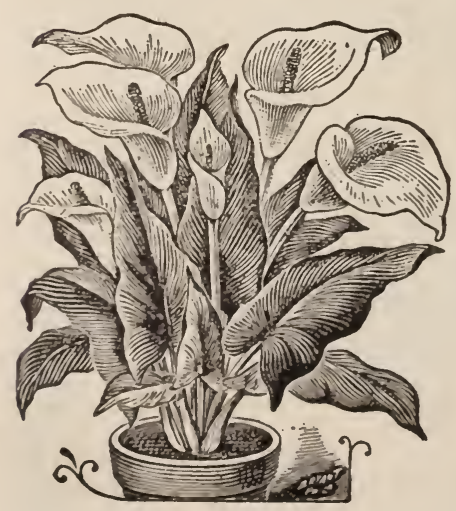

Calla Lily. for room culture, needing little care beyond abundant water, and an occasional washing of the leaves to keep them free from dust. Take a 4 or 5 -inch pot, fill it with good, rich loam ( $\frac{1}{4}$ leaf mould and $\frac{3}{4}$ good garden soil) then put in the bulb and cover it about one inch below the surface, water good and place in a dark place for three or four weeks. As soon as it starts growing bring to the light. Too often people are waiting till spring to plant the Calla tubers, then they have lost much of their vitality. They are ready in August and, if planted in the fall, they give the best results. For winter flowering they should be dried from June till October 1st. It is easily done by turning the pots on one side to prevent the rains from wetting the soil, and covering them slightly to keep the sun from drying the roots too much.

First Size Tubers, jumbo size. [Each..............................25c Average Size:Tubers, sure to make at least one bloom. Each . $.15 c$ 


\section{CYCLAMEN-(Alpenveilchen.)}

(READY IN NOVEMBER)

A well known and universally admired plant, producing exceedingly handsome flowers. It grows readily blossoms freely, and remains in bloom a long time. The soil should be equal parts of turfy loam, leaf mould and sand. Plant in September or October in a 5-inch pot, well drained. Keep in a cool light place, watering lightly till growth begins, then water freely and give plenty of light and air. On the approach of cold weath er remove to a warmer situation, the parlor or greenhouse, and keep them near the light.

The stock of bulbs we offer is grown expressly for critical flower lovers.

Cyclamen Persicum Giganteum.-Separate colors, white, red, rose. Each 25c, per doz. $\$ 2.00$ or one bulb of each color for $60 \mathrm{c}$. All postage paid.

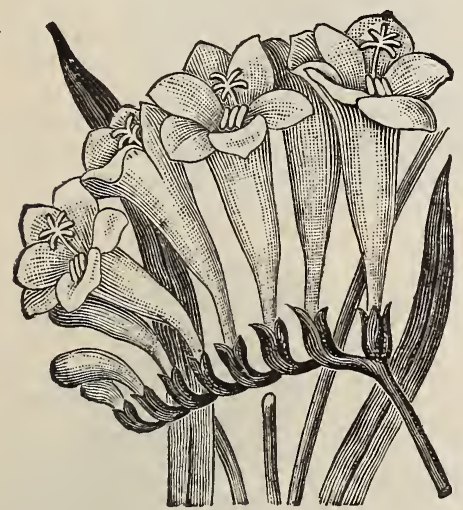

Freesia.

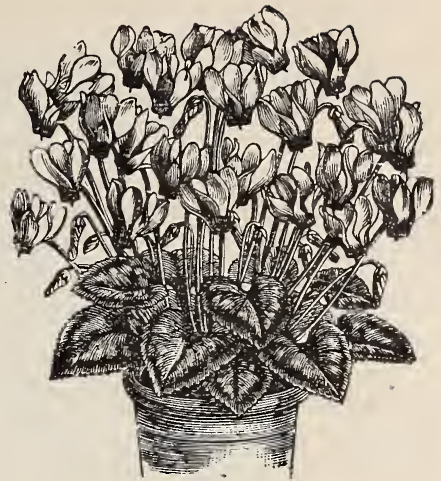

Cyclamen.

\section{FREESIA.}

\section{(READY IN SEPTEMBER)}

This is one of the most beautiful of Cape bulbs, possessing a peculiar grace of form, and its fragrance is most delightful, one pot of five or six bulbs being sufficient to perfume a whole house. As cut flowers they are extremely valuable; the unexparicd blooms, opening in water, fill the air with the most delicate perfume, and their endurance is really remarkable. They force very easily, and can be hau in flower at Christmas and continue in succession mintil June. When potted, they should not be laced in a dark roor.1, like most other bulbs, but shoud le put directly in the light. They will stand a slight frost with no apparent injury.

Freesia Refracta Alba, pure white, California grown...............................\$0 $\$ 02$

Freesia, pure white French grown .05

\section{0}

Each Doz.

\section{LILY OF THE VALLEY.}

\section{(READY IN NOVEMBER)}

When started in open ground they increase rapidly and make a very attractive shady corner of the flower garden. They force easily, and a 7 -inch pot will take from 20 to 25 pips which should be about 1 inch above the surface. Keep them in a cool, dark place until about a montr before wanted in bloom, then take to the light in a warm room.

Best German Pips. Ready to bloom, per dozen, 30 cents, postpaid.

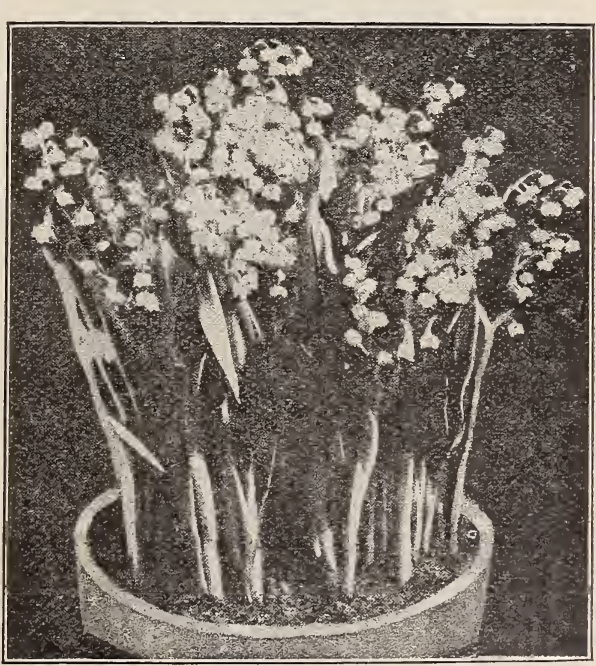

Lily of the Valley. 


\section{LILIES-(Lilium.)}

(Lilium Harrisii and L. Candidum ready in August, all the others not until November)

The bulbs should be planted in the autumn, or as soon in the spring as the frost is out of the ground, on a well drained place. Dig the soil deep and mix plenty of well rotted manure. Set the bulbs four or five inches deep, and, when well started, they should not be disturbed for several years. For forcing, plant them in five or six-inch pots, in a compost of $\frac{1}{2}$ good garden loam, $\frac{1}{4}$ well rotted manure, and $\frac{1}{4}$ sharp sand. Just cover the bulbs, press the soil firmly around them, water good and put them away in a cool place. When the pots are well filled with roots remove them in the house, and force slowly, keeping the temperature cool (about 60 degrees) until the buds appear, then water oftener and increase the heat until they are in full bloom. When in full bloom if they are kept in a dry, airy, cool place the flowers will last longer.

Harrisii. This is the variety used by florists for Easter, it is a magnificent pure white. Large size, 3 to 5 flowers.............................................. Each $25 \mathrm{c}$; per dozen $\$ 2.25$, postpaid Longiflorum Multiflorum. Pure white trumpet flowers, resembling the Harrisii.

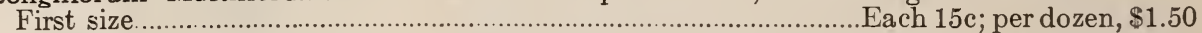
Candidum, Annunciation Lily. One of the finest for the garden. Must be planted in the fall. Each 15c; per dozen, \$1.35, postpaid.

Auratum. The true golden-banded Lily of Japan (see cut) is perfectly hardy and increase from year to year. Should be in every garden. Large size, each 20c; per dozen \$1.75, postpaid

Speciosum Rubrum. A beautiful Japan variety, with six broad white petals, spotted with

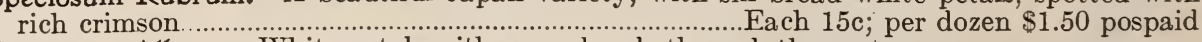
Speciosum Album. White petals with green bands through the center.

Each $15 \mathrm{c}$; per dozen $\$ 1.50$, postpaid

Tigrinum Flora Pleno. The old fashioned Double Tiger Lily. Much admired for its stately habit, bearing immense clusters of blossoms of orange red, spotted with black.

Each $15 \mathrm{c} ; 4$ for $50 \mathrm{c}$; per dozen $\$ 1.25$, postpaid

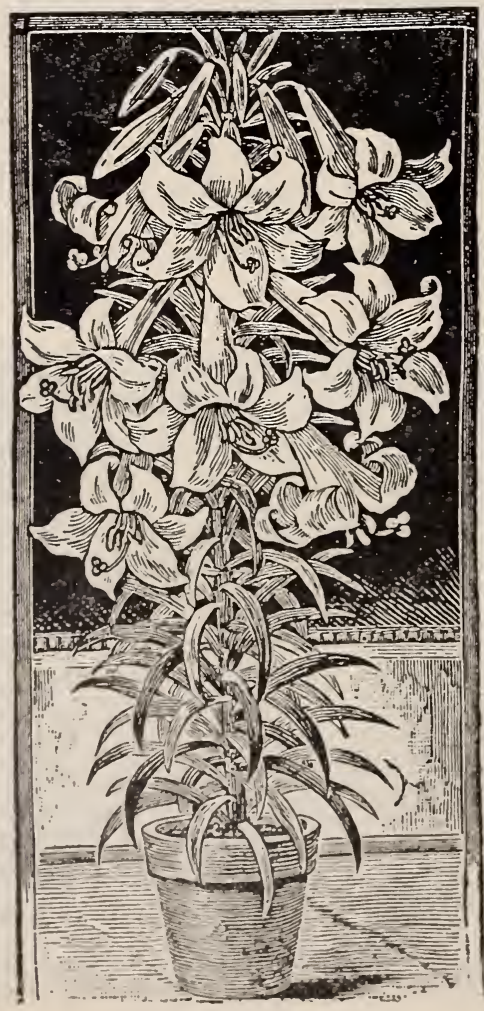

Lilium Harisii.

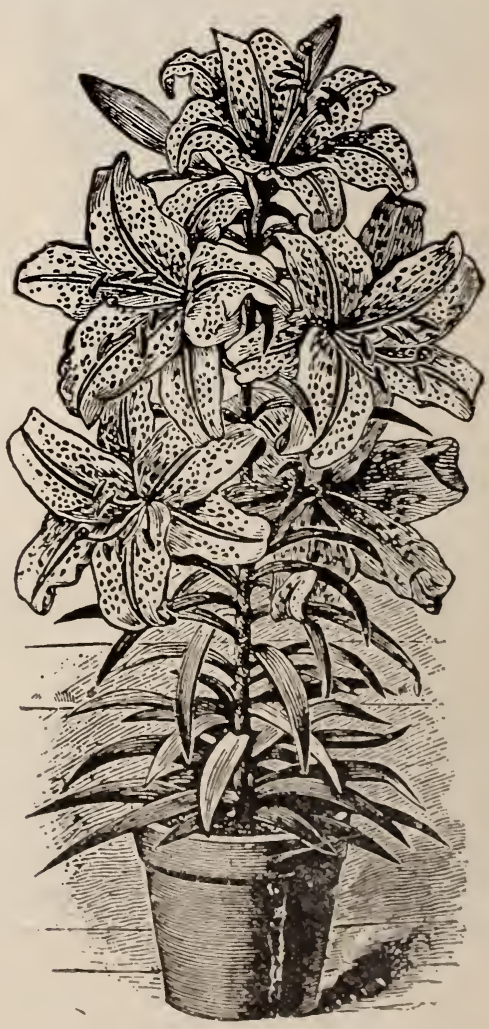

Lilium Auratum. 


\title{
THE BEST HERBACEOUS PAEONIES.
}

\author{
(READY IN OCTOBER)
}

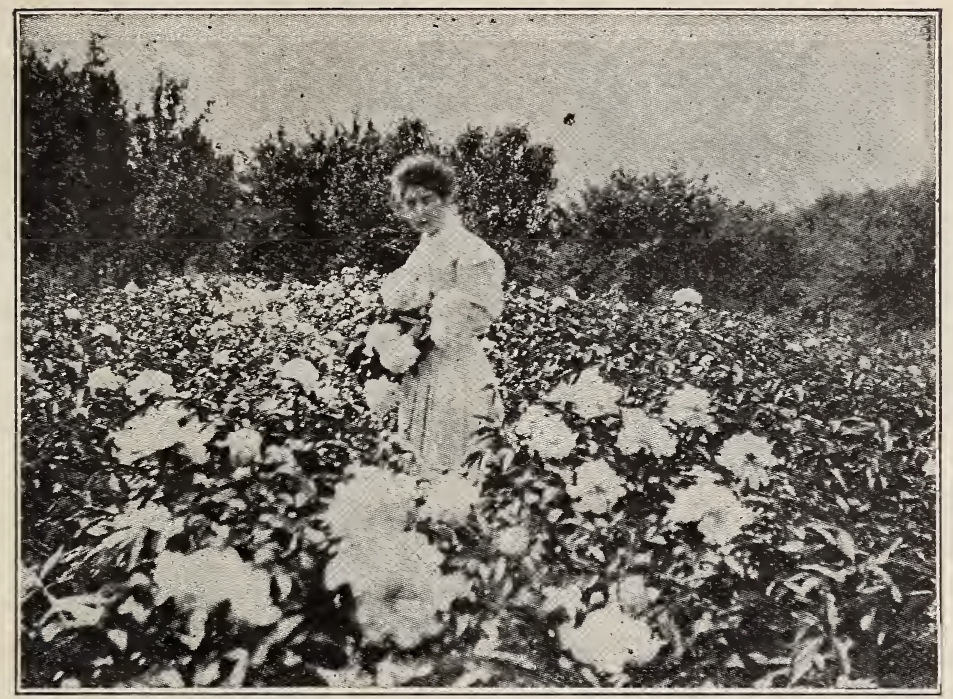

Truly "the lilies in all their glory" do not offer a more refreshing sight than well planned groups of Paeonies. Their abundance and wealth of flowers, which rival the finest rose in roloring, produce a most gorgeous effect during the flowering season.

Paeonies are absolutely hardy, and, after once being firmly established, will take care of themselves, making larger plants and producing a greater number of flowers year after year. Their culture is the easiest, any good garden soil being fit for their development. Should there be a prolonged drouth in the spring, water them a few times as this will promote a strong, healthy growth of foliage, which is necessary to insure perfect blooming qualities.

The following selected varieties have been chosen from hundreds of spiendid sorts, and we can safely call them "the cream" of the best and most widely cultivated. All have been grown on Kansas soil for years, are thoroughly acclimated, and can, we are sure, be successfully raised by every garden lover. Time of blooming, May-June.

CULTURE.-Plant them as soon in the fall as possible, from 5 to 6 inches deep, 2 to 3 feet apart, putting some well-rotted manure in the bottom of each hole. Press the ground carefully around the roots, being careful not to break the crown. Water the spot in the spring, if the weather is dry.

\section{DOUBLE-FLOWERED FORMS OF PAEONIA SINENSIS.}

CHIIIE. Each Doz

FESTIVA MAXIMA. One of the grandest varieties in existence! The standard of perfection

: in Paeoniaes. It is a strong grower, early, very freely flowering and very fragrant. The magnificent flowers are of delicate pure white color, with some of the center petals flaked with carmine. The most popular white Paeony today.

FLORAI TREASURE. This variety has few if any superiors as a cut flower. It is an excellent bloomer, bearing fine, large blossoms on strong, stiff stems. Color of flowers: a bright, light pink

FRAGRANT ROSE. Of dark red color, very fragrant and a late bloomer..

GOLDEN HARVEST. (Jeanne d'Arc.) Exceptionally free flowering and very showy. The attractive blossoms are of a clear yellow color with blush guards, while the center is white with carmine tips. One of the earliest and best.

HUMEI. A late flowering sort of rich brilliant rose color. Very fragrant and exceedingly freeflowering. Blossoms are very large.

LADY BRAMWELL. Produces large flowers of a beautiful silvery rose color.

LA ESPERANCE. A splendid variety for florists as it is an excellen bloomer and fragrant as a rose. The flowers are of dark rose color, very compact and of splendid shipping and keeping

QUEEN VICTORIA. Very early, white, and extremely popular with florists. It produces white flowers with creamy center tipped with red. extra large, verv full blossoms. Color, a deep blood-red

DOUBLE WHITE, MIXED. This lot contains many unnamed seedlings of surprising beauty... DUOBLE PINK, RED AND R,OSE. MIT:SD. Containing a splendid assortment of the most 


\section{OXALIS.}

\section{(READY IN SEPTEMBER)}

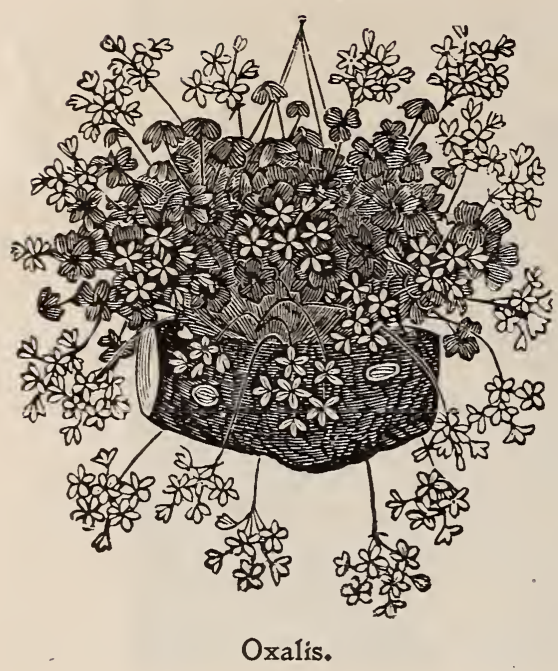

Is well adapted for growing in the house, and is not surpassed in beauty by any other window plants. It blooms freely, lasts a long time, and is free from insects. The best varieties for winter blooming are the Bermuda Buttercup, with Flowers bright, buttercup yellow, produced in great profusion. Take a 5 or 6 inch shallow pot, or, better, a hanging basket, fill with good soil and insert 6 to 8 bulbs 1 inch below the surface; water and put away for 3 or 4 weeks, in a dark, cool place to root thoroughly. Then bring to light and heat. In about 6 weeks they will form a fountain like mass of foliage and flowers.

Bermuda Buttercup, yellow single

Each Doz. 100

Bermuda Buttercup, yellow double. $\$ 0.03$

$\$ 0.25$ $\$ 1.50$ Mixed Colors.

\section{RANUNCULUS. \\ (READY IN SEPTEMBER)}

Like Aanemones they are well adapted for forcing, and the striking beauty of the flowers will amlpy repay the work. Fill a 5 -inch pot with good porous, rich soil; insert 3 or 4 bulbs, covering about 1 inch, water and keep in a cool moist place until well rooted. A few reeks before wanted to bloom bring them to the light, avoiding too much heat and dry air. The individual blossoms are about 2 inches in diameter and perfectly double. For out of doors plant in a well drained rich place, protected from the sharp winds and too much sun, covering about 3 inches deep, and press the earth close around the bulbs. On the approach of very cold weather the beds should be protected with straw or course manure. They will do pretty well if planted in the spring as soon as the frost is out of the ground.

French, large double flowers rich colors and abundant bloomers-15c per dozen, $\$ 1.00$ per 100 ,

\section{SNOWDROPS-(Galanthus Nivalis.)}

\section{(READY|IN|SEPTEMBER)}

The very" first to bloom in the spring, defying snow and chilling winds; they are flowers of the wild and cannot $€$ ndure culture and refinement. A sunny situation does not agree with them, but plant them under trees or shrubs, where the shade is too dense for grass, where the soil is naturally moist, and they will thrive vigorously. Plant the bulbs as soon as they can be gotten, as the vitality soon dries out, about 2 inches deep and let them alone. In a few years they will cover the ground.

Doz. 100

Singleflower, pure white, postpaid........................... $\$ 0.15 \quad \$ 1.00$

Double flower, pure white, postpaid …................... $\quad .25 \quad 1.50$

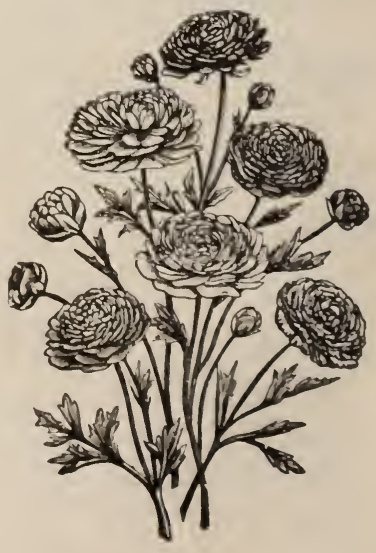

Ranunculus. 


\section{SCILLAS.}

They are entirely hardy and thirve in almost any garden soil. They should be planted in October or November about 2 inches deep in clumps or masses, placing the bulbs one inch a part. The flower s appear early in the spring, before the leaves, and when these come they should not be disturbed as long as they are green or it will be injurious to the bulbs. The Scillas make a very fine contrast with the Snowdrops and Crocus. If wanted to bloom in the house 8 or 10 bulbs should be inserted in a 5-inch pot, covering the bulbs about half an inch deep, water and put in a cold place to root. Water as often as earth shows dryness.

Scilla Siberica, the best for forcing. The flowers are true ultramarine blue, and borne on graceful spikes of 6 to 12 blooms each. 3 or $10 \mathrm{c}$; per doz. $30 \mathrm{c}$; per $100 \$ 1.25$, postpaid.

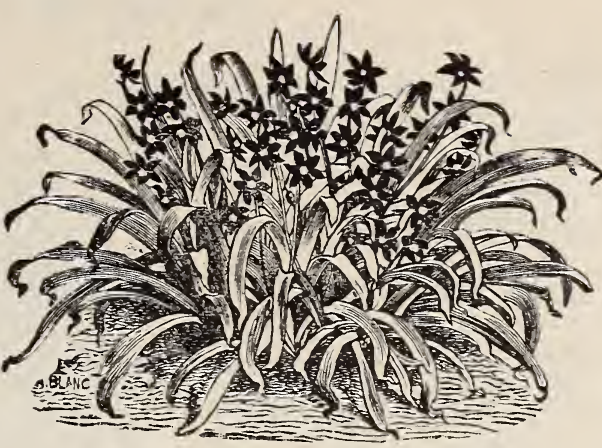

Scillas.

\section{JAPANESE IRIS-(Iris Kaempferi.)}

\section{(READY IN OCTOBER)}

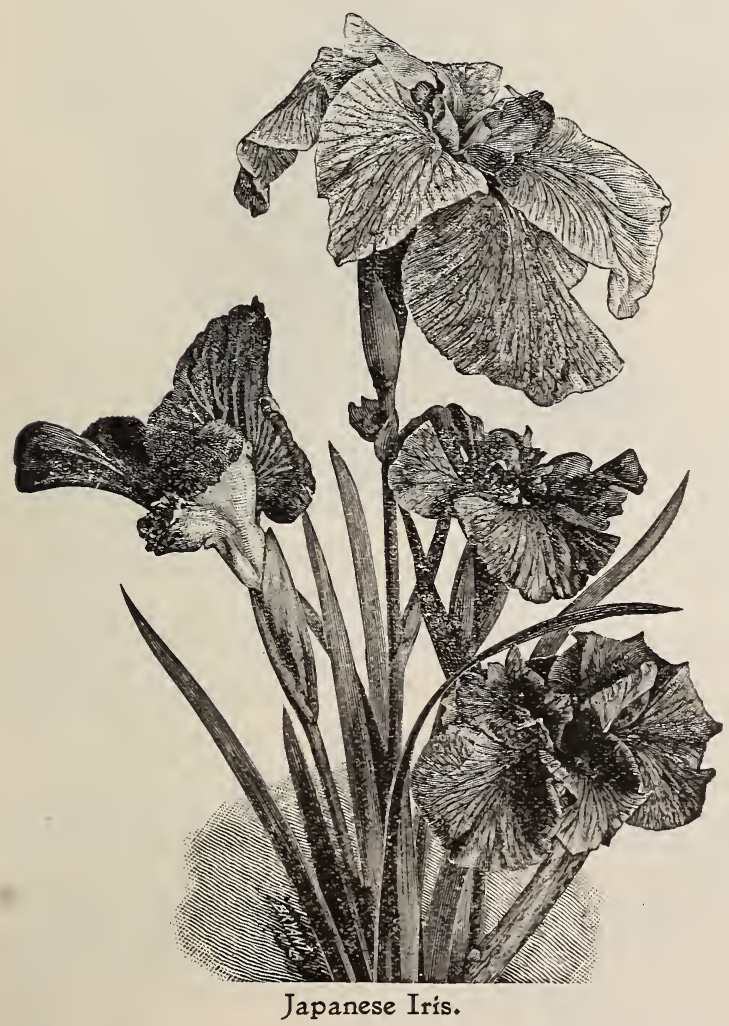

Words are utterly inadequate to express the beauty and magnificence of these lovely flowers. With the ancients the Greek word "Iris" stood for the "Goddess of the Rainbow," and this name was justly applied to these superbly colored flowers. Their size varies from 6 to 8 inches across. The colors represent a most charming blending of many hues, ranging from white to crimson, lavender, lilac, and blue, with many other colored spots and blotches, giving the whole flower the appearance of watered silk in the sunlight.

The Japanese Irises are perfectly hardy, attaining their greatest perfcetion in moist soils, or if watered frequently while they are growing and blooming. They bloom in July, producing flowers in greatest profusion.

The varieties named below are selected from the best Japanese importations. The names are those given to them by the Japanese growers, which will, no doubt, interest our customers.

Ho-o-jo, ruby crimson, blotched primrose, lined with pure white.

Kuma-funjin, purple overlaid with blue.

Komachi-guma, blue and purple, heavily feathered with white, yellow blotches.

Osho-kun, tyrian blue, yellow blotches, radiating into white.

Yomo-no-umi, lavender blue, petaloid stigmas red-lavender.

Strong divisions of each of the above.

Price: $25 \mathrm{c}$ each; 2 for $45 \mathrm{c} ; 3$ for $65 \mathrm{c}$; the collection of five for $\$ 1.00$. All postage paid. 


\section{SELECTED VEGETABLE SEEDS}

\section{SUITABLE FOR FALL PLANTING.}

Cabbage-Sow in September and winter in cold frame

Early Jersey Wakefield.

Early Winnigstadt.

So. 05

Succession

All Seasons.

Endive-Sow in August or September.

Large Green Curled..

Broad Leaved Batavian

Kale-Sow in August or September.

Dwarf Green German..........

Tall Curled Scotch..

Lettuce-Sow in September or October for winter use.

White Seeded Tennis ball..

Barteldes French Forcing...

Barteldes Denver Market...

May King..

Grand Rapids

Radishes-For Autumn sow in August for winter use in September

Crimson Giant Globe.

Non plus ultra.

Rosy Gem..

Deep Scarlet Turnip.
Radishes-Continued

Pkt.

Oz.

Scarlet Olive shaped.

$\$ 0.05$

French Breakfast................................. .05

Long White Icicle ..................................... . .05

White Strasburg.

WINTER VARIETIES.

Round Black Spanish (Winter Rettig) $\quad .05 \quad .10$

Long Black Spanish................................. . .05 .10

California Mammoth White................. . .05 .10

Spinach-Sow in August and September

Long Standing......................................... $\quad .05 \quad .10$

Thick Leaved Viroflay............................. $\quad .05 \quad .10$

Victoria................................................... $\quad .05 \quad .10$

Savoy Leaved........................................... $\quad .05 \quad .10$

Turnips-Sow in August or Septem-

ber. Fine for table use or stock feeding.

Early White Milan................................. .05 . .0

Purple Top Strap Leaved...................... $\quad .05 \quad .10$

Pomeranian White Globe........................ $\quad .05 \quad .10$

Yellow or Amber Globe ........................... . .05 . $\quad .10$

Seven Top (only grown for the tops

which are used as "greens") .............. $\quad .05 \quad .10$

$\begin{array}{lll}.10 & \text { Yellow Purple Top Ruta Baga } \ldots \ldots \ldots \ldots . . . . . & .05 \\ .10\end{array}$ application.

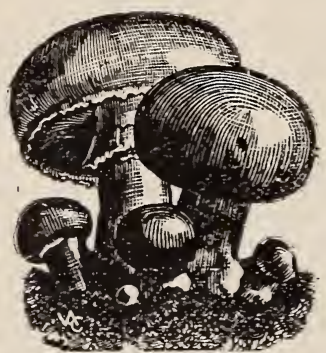

Mushrooms.

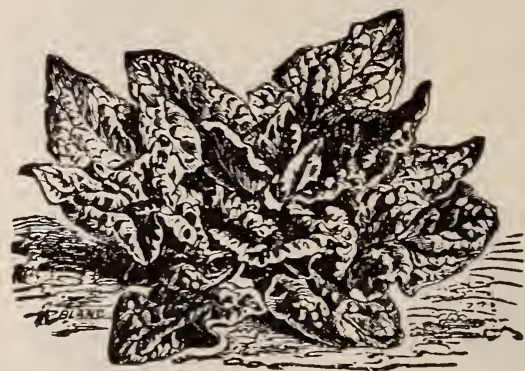

Long-Standing Spinach.

Mushrooms can be grown at home,. Free circular of Mushrooms with each order.

Pure Culture Spawn.

1 brick, by mail....

$\$ 0.35$

By express at purchasers' expenst:

4 bricks, by mail

5 bricks.

$\$ 120$

10 bricks................................................ 2.15

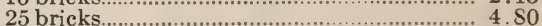

\section{LIST OF FLOWER SEEDS. FOR DESCRIPTIONS SEE OUR GENERAL CATALOG.}

: Many sorts of flowers will succeed best if'sown in the fall. Some hardy plants will start growing at once, while others will lie dormant till the next sprlng, but will start earlier, thrive better and bloom sooner than if sown in the spring.

Ageratum Mexicanum

Alyssum, Sweet.

Candytuft, white.

Carnation, German mixed

Carnation, Marguerite

Cineraria Hybrida

Chrysanthemum

Centaurea

Columbine (Rocky Mountain)

Daisy, double, mixed

Forget-me-not.

Foxglove

Bollyhock
Pkt.

So.05

Larkspur

Matricaria (Double Feveriew)

Mignonette

Pans y, large flowering, mixed

Phlox, Drummondii, large flowering, mixed

Phlox, perennial

Pinks

Poppy, annual

Poppy perennial

Sweet Williams, double mixed

Sweet Peas, all kinds, mixed

Verbena, fine mixed.
Pkt. so. 05

.10

.05

.10

.10
.15

05

.05

.10

05

05 


\section{BARTELDES' SELECTED WINTER SEED WHEAT, RYE AND BARLEY.}

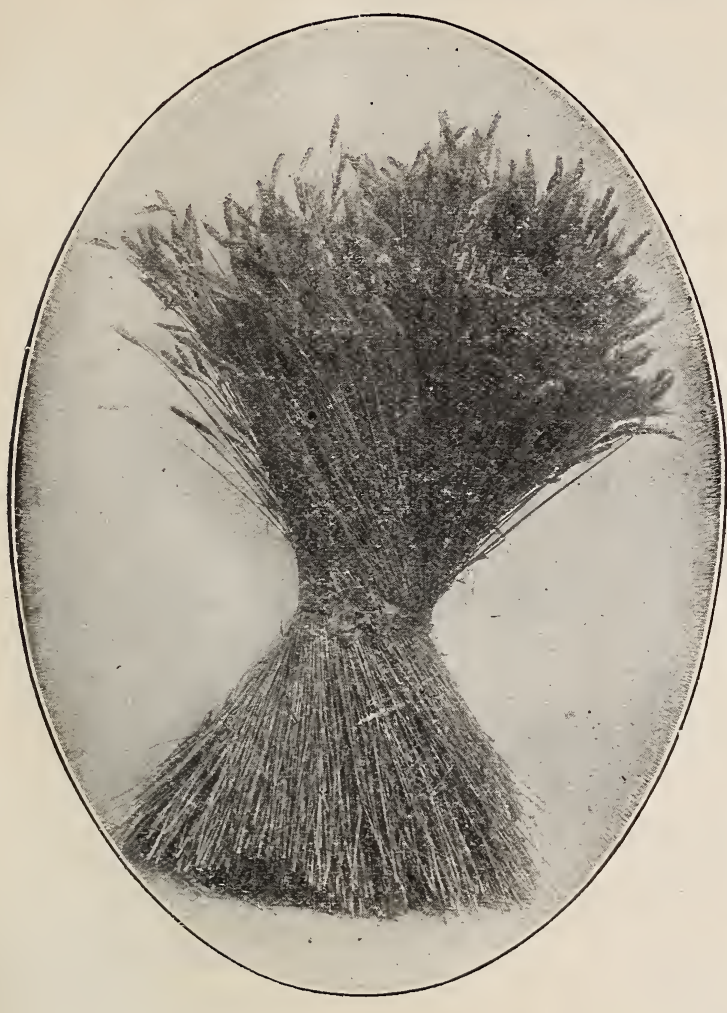

Prices subject to market changes. All quotations include bags, delivered f. o. b. Lawrence.

Prices on larger quantities, as well as samples, sent on application.

\section{HARD WHEATS.}

THE KIARKOV is considered one of the best varieties amongst the hard red Winter Wheats. Our State Agricultural School as well as the Experiment Station of the U. S. Department of Agriculture have given to it the first place, and attention of the farmers has repeatedly been called to this magnificent variety. It is adapted to almost any section of our state and can be highly recommended. Being of the Russian type, it is one of the hardiest varieties. The berries hard plump and red. One of the best yielding varieties of all the red Russian wheats ever introduced.

Price, $\$ 1.50$ per bushel. 10-bu. lots $\$ 1.35$ per bu.

RED RUSSIAN. An exceedingly hardy variety, highly recommended by the Government Experiment Stations. It is very prolific and does well on upland or second bottom lands. Straw rather short but stiff, carrying good square well filled heads.

Price. $\$ 1.50$ per bu.

10-bu. lots $\$ 1.35$ per bu.

\section{SOFT WHEATS.}

PRICES FOR ALL VARIETIES: $\$ 1.50$ per bu.; 10-bu. lots $\$ 1.35$ per bu.

HARVEST QUEEN. This variety is a good yielder of golder yellow color. Some yields in 1909 averaged 35 bushels per acre. It is a wheat of splendid milling qualities.

HARVEST KING. is a red chaff wheat, not so extensively grown as some of our standard varieties. It has a fine stiff straw; average yileds the past season were 28 bushels to the acre.

FULTZ. A very old variety and well known. Will do well in almost any section, but is especially adapted for bottom lands, where it gives splendid returns.

PEARL'S PROLIFIC. We recommend this variety very highly. We have grown it for the past four years and are well pleased with it. The well filled heads (often 4 grains to the mesh) are carried by fine stiff straw which stand up very well. It is a variety that will do fine in low or bottom lands and will bring splendid returns.

RED CROSS is a new variety in this country. It is about a week earlier than the standard varieties, with the exception of the Early May. It is a heavy yielder, and has a golden yellow color. Some fields of this variety averaged 34 bushels per acre this season.

\section{RYE.}

Winter Rye is a valuable crop for either soiling, green fodder, straw or grain. It is largely sown in the fall, being preferred to Wheat for this purpose, as it protects the young grass, which is usually sown with it and because it matures two weeks earlier in the summer than wheat. Rye is also used extensively for fall pasture and for cutting green in late spring or early summer, but when wanted for cutting green, it is best sown with Winter Vetches, offered on next page. Per bu., $\$ 1.10 ; 10 \mathrm{bu}$. lots at $\$ 1.00$ per bu.

\section{WINTER BARLEY.}

This is usally sown around October first and although Barley will do comparatively well on thin or poor soils, yet the yields are most profitable on fertile and rich ground. It stands the winter well, and will make splendid growth throughout the season. Winter Barley is usually ready for harvesting a week or ten days before Winter Wheat, and two weeks before Spring Barley. In favorable seasons Winter Barley yielded as high as 65 bushels per acre. We recommend it highly. Two bushels will sow one acre. 


\title{
FINEST RE-CLEANED GRASS and CLOVER SEEDS.
}

\author{
Prices Fluctuate. Ask for latest quotations on large quantities
}

For years we have made a specialty of carrying the most selected quality of these seeds Everything sold is Selected with special reference to Quality, and it is our constant aim to supply nothing but the freshest and purest and choicest seeds, free from foreign and noxious weeds.

\section{Bury from us and get the best.}

Note.- If Grass and Clover Seeds are to be sent by mail, be sure to add 8 cents postage. for every pound ordered.

\section{GRASSES.}

RED TOP GRASS. (Agrostis vulgaris.)

Usually sown with timothy and clover to form a close sward for pasture. 15 pounds will sow one acre.

Fancy Hulled, per lb., 20c; per 100 lbs., $\$ 15.00$.

ORCHARD GRASS. (Dactylis glomerata.)

A fine pasture grass and also splendid for producing large crops of hay. Succeeds quite well in shady places. $30-40$ pounds to the acre.

Per lb., 20c; per 100 lbs., $\$ 16.00$.

TIMOTHY. (Phleum pratense.)

Splendid for raising large crops of hay. Generally sown with winter grain in the fall. From 15 to 20 pounds are sown per acre.

Per lb., 10c; per 100 lbs., $\$ 5.00$

BROME GRASS. (Bromus Inermis.)

A very leafy, fine-stalked grass of great droughtresisting qualities. It makes very quick growth, producing splendid pasture and fine crops of hay About 20 to 25 pounds will sow an acre.

Per lb., 15c; per 100 lbs., $\$ 10.00$

ENGLISH RYE GRASS. (Lolium perenne.)

This is particularly adapted for cool, moist locations and will make a quick growth early in the spring. 15-20 pounds are sown per acre.

Per lb., 10c; pr 100 lbs., $\$ 8.00$

MEADOW FESCUE OR ENGLISH BLUE GRASS

(Festuca pratensis)

A well known Kansas grass, being an excellent pasture grass, as it is highly relishod by cattle. 15-20 pounds to the acre. Per lb., 20c; per $100 \mathrm{lbs}$, \$18

KENTUCKY BLUE GRASS. (Poa pratensis.)

The standard American grass for pastures, as wel! as lawns. Sow 30-40 pounds per acre; for lawns about twice that quantity.

Per lb., 20c; per 100 lbs., $\$ 15.00$

\section{CLOVERS.}

RED CLOVER. (Trifolium pratense.)

Next to Alfalfa it is considered the most important of the clovers. Makes excellent hay, and can be cut twice a year. Sow 12-15 pounds to the acre.

Per lb., 15c; 100 lbs., $\$ 13.00$

MAMMOUTH SAPLING OR PEAVINE CLOVER

This grows much taller than Red Clover and is also somewhat later in ripening. Does very well, if mixed with Timothy, Red Tos, etc. Sow 12-15 pounds per acre.

Per lb., 15c; per 100 lbs., $\$ 14.00$

WHITE DUTCH CLOVER. (Trifolium repens.)

Excellent for pastures as well as used for lawns. It is of low creeping growth and succeeds well most anywhere. $\quad$ Per lb., 20c; per 100 lbs., $\$ 17.50$

ALSIKE CLOVER. (Trifolium Hybridum.)

A splendid clover for sowing with other grasses, either for pasture or hay. It is very hardy, thrives well in either dry or wet soils, growing much taller than the Red Clover.

Per lb., 20c; per 100 lbs., $\$ 17.50$

CRIMSON CLOVER. (Trifolium incarnatum.)

This clover is a great soil improver, restoring poor land to fertility. It is also valued for the immense quantities of fodder which it yields. Seed should be sown early in August or September so that it will be firmly established before winter.

Per lb., 15c; per 100 lbs., $\$ 10.00$

ESPARSETTE OR SAINFOIN CLOVER. (ONObrychis sativa.)

Splendid Clover for dry land farming. Shorter lived plant than alfalfa, but will live from 8 to 10 years, according to soil, by judicious top dressing of manure. Per lb., 15c; per 100 lbs., $\$ 12.50$

For Alfalfa see back cover.

\section{OTHER FIELD SEEDS FOR FALL SOWING.}

\section{DWARF ESSEX RAPE.}

Grown largely for pasturing hogs or sheep in the fall as it is very fattening. It may be sown in Kansas from end of August until the middle of September; in more southern states not until the end of Scptember or October. It does well if sown with oats. If the soil is rich and clcan of weeds, sow broadcast at the rate of 8 to 10 pounds per acre. If the soil is thin, plant in drills and cultivate the same as corn. Villosa)

The Sandvetch prospers on the most barren soils, on those too poor to grow any other crop. Six tons per acre of grcen forage have been harvested in peut in poor silicious soils with second cut of in one cut in poor silicious soils with second cut of seed or for plowing under. Sow end of August
alone or with a cereal, rye preferred, as this vetch reaches a height of $3 \frac{1}{2}$ to 5 feet, and must have a support. Sow 60 to 75 pounds per acre. If it inakes good growth before winter, it may be cut. and again by March 15 . Eaten by all farm stock. Per lb., 15c; ner 100 lbs., $\$ 10.00$ 

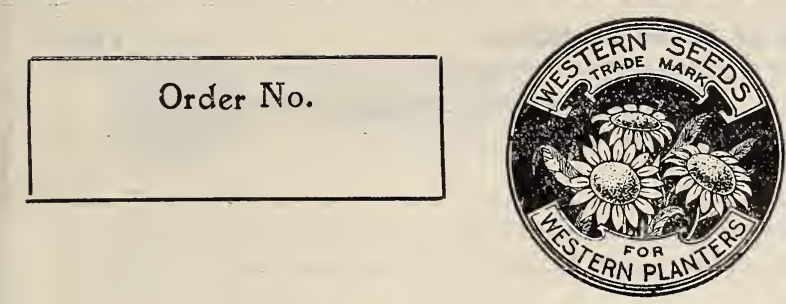

Date Received

\section{The Barteldes Seed Co. LAWRENCE, KANSAS.}

PLEASE WRITE NAME AND ADDRESS PLAINLY.

Date.

Send by $\begin{gathered}\text { State whether by Mail, } \\ \text { Express or Freight }\end{gathered}$

SEND MONEY WITH ALL ORDERS.

Name

\section{Post Office}

County

R. F. D.

State

Express or Freight Office

Express Co. or Railroad

No Goods Sent C.O.D.

AMOUNT ENCLOSED:

P.O. Order \$

Draft - S

Exp. Order \$

Cash - \$

Stamps $-S$

Total S

Quantity NAMES OF BULBS OR SEEDS.




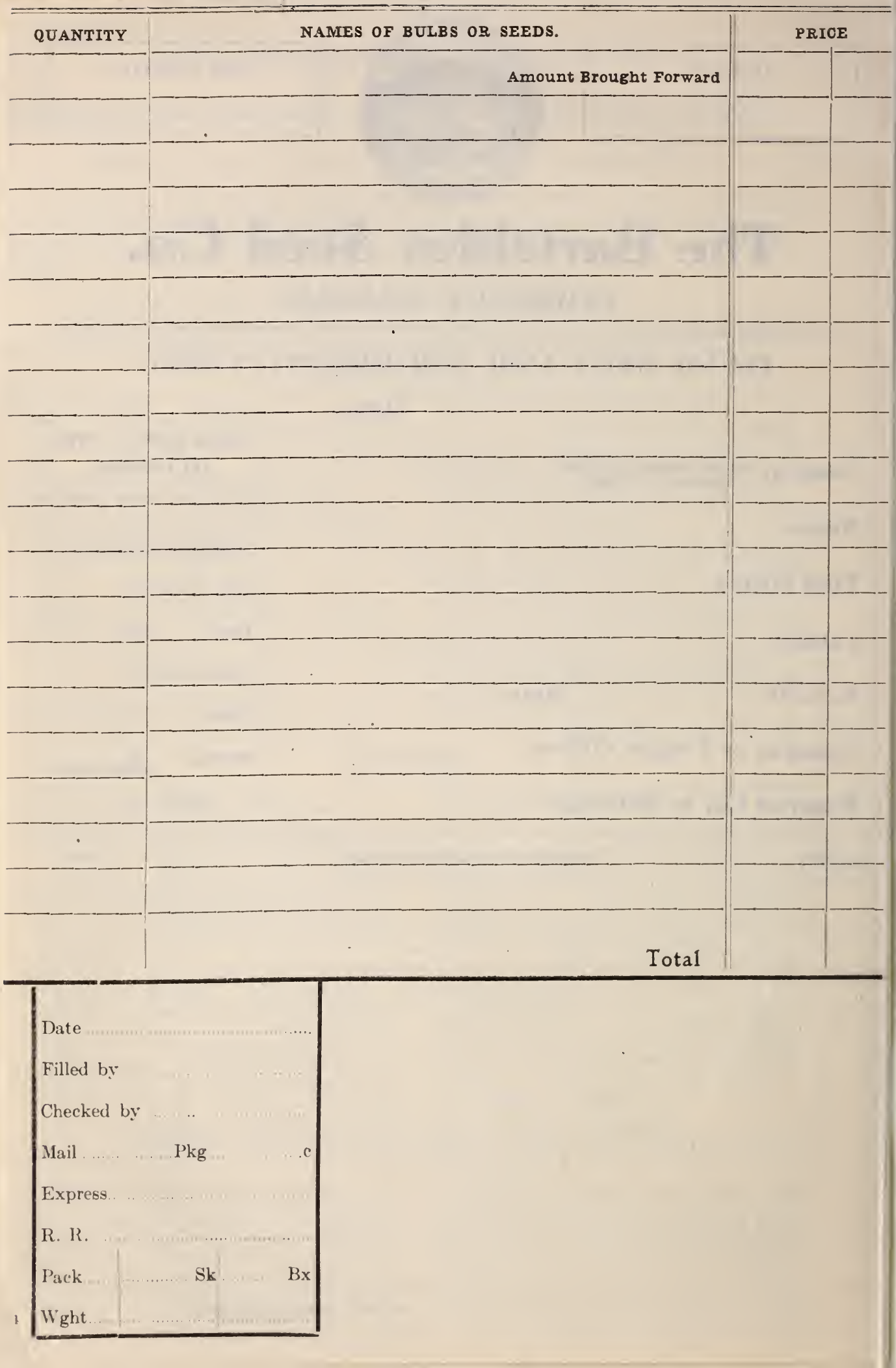




\section{BARTELDES' "SUNFLOWER BRAND" of FINEST LAWN GRASS MIXTURE.}

produces splendid lawns wherever sown. No one particular kind of grass seed is suitable for producing good lawns, but it takes a well-balanced mixture to suit the requirements of different climes and soils.

Our "Sunflower Brand" is a mixture of various native and foreign fine-bladed grasses of deep-rooting, interweaving habits, which will grow under various conditions of soil and climate during the different seasons of the year. It will make perfect and lasting lawns of luxuriant richness, maintaining its velvety appearance throughout the summer and fall.

There are other Grass Seed Mixtures, but there are none better. Our "Sunflower Brand" is a mixture that will last! No cheap chaff, but good heavy seed of splendid germination power. The measured bushel of "Sunflower Brand" Lawn Grass weighs uniformly 20 pounds as compared with 14 pounds weight of other standard mixtures.

Full culture directions as to how to prepare and how to keep a fine lawn will be found on every package. It is put up in attractive cartons of one pound each, or in bulk.

As a guide for the proper quantity to offer, we may state that one pound of Fancy Mixed Lawn Grass Seed is sufficient to thoroughly sow an area of 10 feet by 15 feet- 150 square feet; or to cover an acre 65 to 80 pounds will be required. It should be born in mind that in order to produce the best results, grass seed for lawns should be sown at least twice as thickly as if sown for hay.

As soon as the grass has become well established a dressing of good Lawn Fertilizer is necessary to keep up that beautiful fresh appearance.

Price of cartons, containing $1 \mathrm{lb}$ each. $30 \mathrm{c}$

Mailed postpaid upon receipt of price:

In bulk,transportation charges to be paid by customers, per 1b., 25c; per $100 \mathrm{lbs}$.,

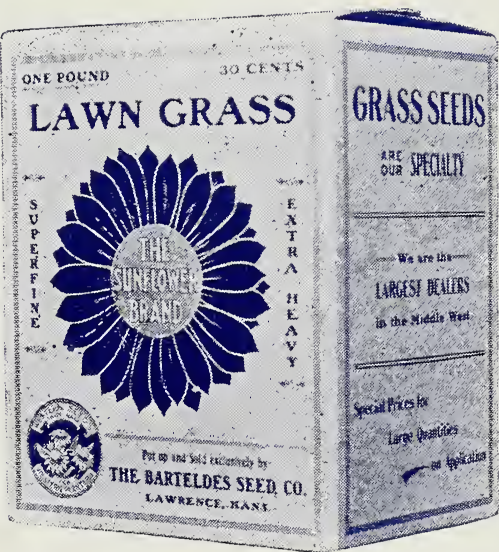

\section{Poultry}

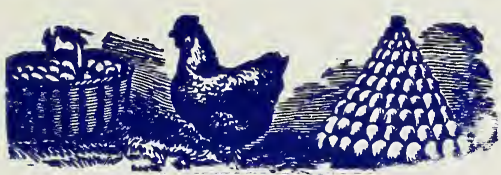

\section{Supplies}

Barteldes' Chicken Feed.

A well balanced feed for grown chickens, put up in 100 pound sack. of Kansas and sold under a guaranteed analysis.

Barteldes' Chick Feed.

Price $\$ 1.75$ per 100 lbs. ut up and registered the same ly for Chicks.

Fine Dried Blood Meal. A highly concentrated and natural food for hens containing 87 per cent Protein. Makes the plumage bright and glossy, and is particularly beneficial during the moulting season. Should never be fed without mixing with other food in proportion of 1 to 15 parts of meal or shorts.

Price 1b. $5 \mathrm{c} ; 10$ lbs. $40 \mathrm{c} ; 100$ ibs. $\$ 3.75$.

Coarse Poultry Bone. Consists of ground beef bone thorouhgly dried and free from grease. It is more economical and better in every way than raw beef bone. Rich in Bone Phosphate of Lime, which is so necessary for making egg shells, and for building up the frame of the chicken. Should be placed in liberal quantities in a clean dry place, easily accessible to the chickens at all times. Price $1 \mathrm{~b}, 5 \mathrm{c} ; 10 \mathrm{lbs} .35 \mathrm{c} ; 100 \mathrm{lbs}$. $\$ 3.00$.

Fine Poultry Bone. Is the same as the coarse, but ground finer for, the smaller chickens, and is a great frame builder. It can be mixed with the mash in limited quantities. Price 1b. 5c;101bs.30c;1001bs. $\$ 2.75$

Coarse Meat Meal. Made from cooked beef scraps, thorouhgly dried and ground. Is especially useful for fattening poultry for the market. Is better and more economical than fresh beef scraps, because it is con-

centrated and free from mositure. A great flesh producer. Price lb. 5
Genuine Crushed Oyster Shells. Not clam shells like some dealers offer.

Price 1b. 5c; 10 lbs. 25c; 100 lbs. $\$ 1.00$

Mica Crystal Grit. Best on the market for both old and young chickens.

All registered with the Kansas Agricultural College.

Price 1b, 5c; 10 lbs. 25c; 100 lbs, $\$ 1.00$ 


\section{If If S Seed Our Sunflower Grade Alfalfa Seed is Native Grown.......}

ALFALFA SEED may be sown to best advantage in the eastern sections of Kansas and adjoining territories during July, Angust and September. If Alfalfa is sown when there is sufficient moisture in the land, and the land has been put in fine garden condition, planters are almost certain to secure prompt and sufficient germination to make a good stand.

Keep down the weeds! During the Spring and Summer months the piece of land intended for Alfalfa should have been cultivated repeatedly. Spring sowings have often to be considered a partial failure because the quicker growing annual weeds choke out many tender Alfalfa seedlings. The land should have been so treated that the weed seeds near the surface have had ample time to germinate and be killed by frequent cultivation.

Then, when all the weeds have been killed and your land is in fine shape, the next important thing is the Seed. Our Sunflower Brand Alfalfa is the best in the country. Of highest germination, free from noxious weeds, it is the best that the planters can desire. We consider Native-Grown Alfalfa the best on the market and shall supply the same as long as we have it in stock or can procure it.

$\mathrm{Be}$ sure to ask for Barteldes "SUNFLOWER BRAND" ALFALFA.

Per 1b., 20 cents; per 100 lbs., \$19.00. Quotations subject to market changes.

i i

Prices for larger quantitics or lower grades on application.

Sixteen page booklet on Alfalfa issued by us, sent free.

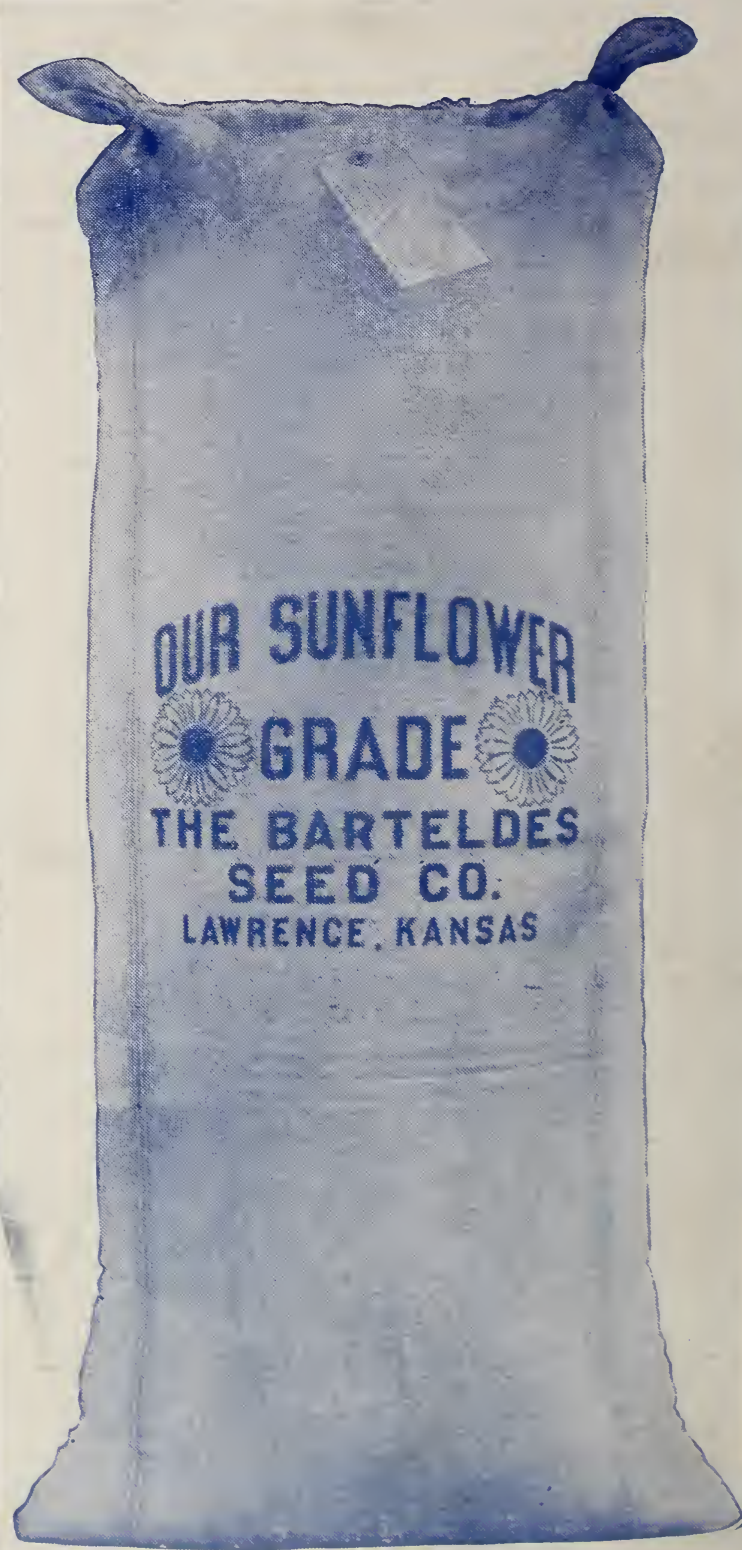

GIVES BEST RESULTS.

\section{The Barteldes Seed Co. Lawrence, Kansas}

